\title{
Study of Some Qualitative and Quantitative Characters of the Grapes of Indigenous Greek Grapevine Varieties (Vitis vinifera $\mathrm{L}$.) using HPLC and Spectrophotometric Analyses
}

\author{
Katerina BINIARI, Orestis GEROGIANNIS, Ioannis DASKALAKIS, \\ Despoina BOUZA, Maritina STAVRAKAKI*
}

\author{
Agricultural University of Athens, School of Agriculture, Engineering and Environmental Sciences, Department of Crop Science, \\ Laboratory of Viticulture,Iera Odos 75, 118 55,Athens, Greece; kbiniari@aua.gr;or.gerogiannis@yahoo.gr;john-daskalakis@hotmail.com; \\ desph@aua.gr; maritina@aua.gr ('correspondingauthor)
}

\begin{abstract}
Grape skins and seeds are sources of various quality characters of grapevine varieties, such as phenolic compounds, anthocyanins, resveratrol etc. The Greek vineyard is characterized by a large number of indigenous grapevine varieties which remain almost unexploited in terms of their different phenolic content. The aim of this study was to assay the polyphenolic content of seven red native Greek grapevine varieties ('Kolliniatiko', 'Bekari', 'Bakouri', 'Kountoura mavri', 'Doubrena mavri', 'Thrapsa', and 'Mavro Spetson') using high performance liquid chromatography (HPLC) coupled with a diode array detector and spectrophotometer. All studied varieties were cultivated in the same area and under the same conditions. The results revealed that despite the fact that anthocyanins and phenolic compounds content were in high levels for all varieties, statistically significant differences were recorded among them. The highest anthocyanins concentration was recorded in 'Kolliniatiko', while the lowest anthocyanins concentration was recorded in 'Mavro Spetson'. Grapevine variety 'Mavro Spetson' presented the highest concentration of total phenolic compounds, with statistically significant difference compared to 'Kountoura mavri' and 'Bekari'. Grapevine varieties 'Kolliniatiko' and 'Bekari' presented the highest concentrations in transresveratrol and piceid content, while grapevine variety 'Doubrena mavri' presented the highest concentration in vanillin content. These unexploited rare native cultivated varieties contained appreciable amounts of non-colored phenols as well as anthocyanins, meaning that they would be worthy of further study and use for the production of quality wines.
\end{abstract}

Keywords: anthocyanins, grape seeds, grape skins, polyphenols, tannins, Vitis vinifera

\section{Introduction}

The phenolic composition of grapes has been studied by many researchers (Fernández et al., 1993; Vrhovšek, 1998; Pastrana-Bonilla et al., 2003; Kammerer et al., 2004; Mozetič et al., 2006; Nicoletti et al., 2008; Hollecker et al., 2009).

In the past few years there has been an increasing interest in determining relevant dietary sources of antioxidant phenolics and their potentially beneficial effects for human health (Shirkande, 2000).

Resveratrol and other phytochemicals in grapes may reduce the risk of cardiovascular disease. For example, in studies conducted with grapes and grape juice, clinical trials have demonstrated decreased platelet aggregation (PaceAsciak et al., 1996; Folts, 1998; Keevil et al., 2000; Freedman et al., 2001), improved endothelial function (Stein et al., 1999; Coimbra et al., 2005; Lekakis et al., 2005), reduced blood pressure (Park et al., 2004), and positive influences on biomarkers such as HDL, LDL, apoB, and MCP-1 (Hansen et al., 2005; Zern et al., 2005; Castilla et al., 2006). Accordingly, it is apparent that grape consumption can modulate several factors that are associated with health benefits.

Grapes (Vitis vinifera L.) are among the fruits with the highest content of these compounds. A large amount of different phenolic compounds is present in skin and seeds, and they also undergo partial extraction during winemaking processes (Revilla and Ryan, 2000). Phenolics are divided into two groups: flavonoid (anthocyanins, flavan-3-ols, 
98

flavonols) and non-flavonoid compounds (hydroxybenzoic and hydroxycinnamic acids, stilbenes). Every family of polyphenols is directly responsible for the special characteristics of specific grapevine varieties and the resulting wine. Anthocyanins are flavonoids commonly found in plant tissues, responsible for the red, blue, and purple colours of most flowers and fruits. They are glycosylated derivatives of 3,5,7, 30-tetrahydroxyflavylium cation, i.e. anthocyanidin; this aglycon part of the flavonoid structure, is renamed to anthocyanin when glycosylated. Among the different anthocyanidins found in nature, six occur frequently and are of most dietary importance: cyanidin, delphinidin, peonidin, pelargonidin, petunidin, and malvidin. Anthocyanins are important polyphenols in the red grape skin, while flavan-3-ols are the major polyphenols in the seeds (Bourzeix et al., 1986; Cheynier and Rigaud, 1986; Makris et al., 2006). For this reason, grape seed extract has become popular in recent years as a nutritional supplement (Waterhouse et al., 2000). Similar research studies have been conducted mainly in Greek wine grape varieties (Kallithraka et al., 2006; Petropoulos et al., 2017).

The current study investigated the total and individual phenolic composition both in the berry skin and seeds of seven Greek red grapevine cultivated varieties. It should be noted that the studied varieties are cultivated in small surface areas and in multi-variety vineyards, together with other red grapevine varieties. More specifically, the viticultural areas of the studied varieties are the Peloponnese ('Kolliniatiko', 'Bakouri', 'Thrapsa', 'Mavro Spetson'), Epirus ('Bekari'), Attica, Evvoia ('Kountoura mavri', 'Doubrena mavri'). These varieties, because of the black color of the berry skin, are usually included in the large group of varieties under the generic name 'Mavroudia'.

A recent study that employed the ampelographic description and the molecular method SSR has shown that twenty-one (21) grapevine varieties belonging to this large group of the Greek 'Mavroudia' exhibits significant genetic heterogeneity, while high degree of genetic similarity was detected between the varieties 'Mavro Spetson' and 'Kountoura mavri' (Stavrakaki and Biniari, 2017).

The objective of this study was to determine the total and individual phenolic composition of seven red grapevine varieties belonging to the 'Mavroudia' group, both in the berry skin and seeds of these varieties.

\section{Materials and Methods}

\section{Plantmaterial}

Seven red grape native varieties (Vitis vinifera $\mathrm{L}$.) were chosen in order to assay their polyphenolic content. The studied varieties and the viticultural areas in which their cultivation is recommended or allowed according to the Greek legislation are presented in detail in Table 1. It should be noted that these varieties are preserved in the Ampelographic Collection of the Laboratory of Viticulture (Agricultural University of Athens, AUA), from where the samples were collected. The experimental vineyard is located in Athens (coordinates $37^{\circ} 58^{\prime}$ ). The vines are bilateral cordon-trained (bilateral Royat), with $2.2 \mathrm{~m} \times 1.2$ $\mathrm{m}$ distances. The vines are spur-pruned to 1-2 node spurs and the usual viticultural techniques are applied (fertilization: 11-15-15 NPK, dose 250-300 g/vine; canopy management techniques: shoot thinning, topping; irrigation). The experiment took place during the cultivation period of 2015-2016.

\section{Reagents and chemicals}

The different phenolic compounds analysed were identified according to their order of elution and the retention times of pure compounds.

Anthocyanins (cyanidin-3-O- glucoside, delphinidin-3O- glucoside, petunidin-3-O- glucoside, peonidin-3-Oglucoside, malvidin-3-O- glucoside) were purchased from Extrasynthese (Gemay, France).

Non-coloured phenolics were purchased from different sources. More specifically, gallic acid, protocatechuic acid, catechin, vanillic acid, caffeic acid, syringic acid, vanillin, epicatechin, ferulic acid, sinapic acid, m-coumaric acid, $p$ coumaric, and rutin were purchased from Sigma (St. Louis, USA); luteolin, procyanidin B1, procyanidin B2, $\varepsilon$-viniferin, quercetin, trans-resveratrol, and piceid were purchased from Extrasynthese (Gemay, France); and coutaric acid, caftaric acid, and fertaric acid were purchased from PhytoLab GmbH \& Co. KG (Germany).

\section{Bunch mechanical properties (weight, length and width)}

Random bunches from different vines were collected of each grapevine variety. For each one of these bunches, their weight was measured using a precision scale and their length and width were determined using callipers with $0.01 \mathrm{~mm}$ accuracy.

\section{Samplepreparation}

For the berry skin extraction, approximately 100 frozen berries were manually peeled. Skins were dried in a freeze drier. To prepare the extracts, $0.4 \mathrm{~g}$ dried skins were mixed with $4 \mathrm{~mL}$ extraction medium water/methanol/ acetone/HCL (19/40/40/1), homogenized for $1 \mathrm{~min}$ at $8000 \mathrm{rpm}$ in an Ultra Turrax homogenizer and the extracts were shaken in controlled temperature vacuum at $150 \mathrm{rpm}$ for $30 \mathrm{~min}$ at room temperature $\left(25^{\circ} \mathrm{C}\right)$. Samples were centrifuged at $4500 \mathrm{rpm}$ for $10 \mathrm{~min}$. The supernatants were collected and the extraction procedure was repeated two more times. All fractions were combined and the supernatants were stored at $-80^{\circ} \mathrm{C}$ until the analysis.

For the berry seed extraction, $0.4 \mathrm{~g}$ of milled seeds were mixed with $4 \mathrm{~mL}$ extraction medium water/ methanol/ HCL (19/80/1), homogenized for $1 \mathrm{~min}$ in an Ultra Turrax homogenizer and the extracts were shaken in controlled temperature vacuum at $150 \mathrm{rpm}$ for $60 \mathrm{~min}$ at

Table 1. Grapevine varieties studied and sampling areas

\begin{tabular}{cccc}
\hline $\mathrm{a} / \mathrm{a}$ & Grapevine variety $^{\mathrm{a}}$ & Berry skin color $^{\mathrm{b}}$ & Growing region \\
\hline 1 & Kolliniatiko & $\mathrm{N}$ & Peloponnese \\
2 & Bekari & $\mathrm{N}$ & Epirus \\
3 & Bakouri & $\mathrm{N}$ & Peloponnese \\
4 & Kountoura mavri & $\mathrm{N}$ & Attica, Evvoia \\
5 & Doubrena mavri & $\mathrm{N}$ & Attica, Evvoia \\
6 & Thrapsa & $\mathrm{N}$ & Peloponnese \\
7 & Mavro Spetson & $\mathrm{N}$ & Peloponnese \\
\hline
\end{tabular}

a: Transliteration of the original Greek name of variety into Latin characters b. N: noir (black) 
room temperature $\left(25^{\circ} \mathrm{C}\right)$. Samples were centrifuged at $5000 \mathrm{rpm}$ for $10 \mathrm{~min}$. The supernatants $(4 \mathrm{~mL})$ were collected and the extraction procedure was repeated two more times, resulting at a total extraction volume of $12 \mathrm{~mL}$.

\section{Determination of soluble solids, $p H$ and total titratable acidity}

Soluble solids were determined in fruit juice using an ATAGO N1-a refractometer with a 0-32 ${ }^{\circ}$ Brix measurement range with $0.28{ }^{\circ}$ Brix increments, and no temperature compensation. Total titratable acidity was measured by titration with $0.1 \mathrm{~N} \mathrm{NaOH}$ solution. Total titratable acidity was expressed as tartaric acid, the most abundant organic acid in Vitis vinifera grapes.

\section{Determination of total phenols and anthocyanins}

Total phenols and anthocyanins were measured with the method of Somers and Evans (1977) with some modifications. An aliquot of the extract was dissolved in methanol 1:50. To measure anthocyanins and total phenols, $0.5 \mathrm{~mL}$ of the dissolved extract was added to $10 \mathrm{~mL} \mathrm{HCL}$ 1M. Tubes stayed in the dark for $3 \mathrm{~h}$ and the concentration of total anthocyanins and total phenols was determined spectrophotometrically at 520 and $280 \mathrm{~nm}$. The concentration of total phenols was estimated from a calibration curve, constructed by plotting known solutions of catechin $(12.5-200 \mu \mathrm{g} / \mathrm{mL})$. The concentration of total anthocyanins was estimated from a calibration curve, constructed by plotting known solutions of malvidin 3-O glucoside $(12.5-200 \mu \mathrm{g} / \mathrm{mL})$. The results are expressed as mean (milligrams of catechin equivalent per gram of fresh matter).

\section{Determination of total flavonoid content}

Total flavonoid content was determined using a colorimetric method described by Dewanto et al. (2002). An aliquot of the extract was dissolved in methanol 1:50. Briefly, $0.25 \mathrm{~mL}$ of the dissolved extract or catechin standard solution was mixed with $1.25 \mathrm{~mL}$ of distilled water in a test tube followed by addition of $75 \mu \mathrm{L}$ of $5 \% \mathrm{NaNO}_{2}$ solution. After $6 \mathrm{~min}, 150 \mu \mathrm{L}$ of a $10 \% \mathrm{AlCl}_{3} \cdot 6 \mathrm{H}_{2} \mathrm{O}$ solution was added and allowed to stand for another $5 \mathrm{~min}$, and $0.5 \mathrm{~mL}$ of $1 \mathrm{ml} \mathrm{NaOH}$ was added. The mixture was brought to $2.5 \mathrm{~mL}$ with distilled water and mixed well. Absorbance was measured immediately against the blank at $510 \mathrm{~nm}$. The concentration of total flavanols was estimated from a calibration curve, constructed by plotting known solutions of catechin $(12.5-200 \mu \mathrm{g} / \mathrm{mL})$. The results are expressed as mean (milligrams of catechin equivalent per gram of fresh matter).

\section{Determination of total flavanols}

The total flavanol content was estimated using the $\mathrm{p}$ dimethylaminocinnamaldehyde (DMACA) method (Vivas et al., 1994; Li et al., 1996; McMorrough et al., 1996). Extract $(0.2 \mathrm{~mL})$, diluted 1:50 with methanol, was introduced into a $15-\mathrm{mL}$ tube and added $1 \mathrm{~mL}$ DMACA solution $(0.1 \%$ in $1 \mathrm{~N} \mathrm{HCl}$ in $\mathrm{MeOH})$. The mixture was vortexed and allowed to react at room temperature for 10 min. Following this, the absorbance at $640 \mathrm{~nm}$ was read against the blank. The concentration of total flavanols was estimated from a calibration curve, constructed by plotting known solutions of catechin $(12.5-200 \mu \mathrm{g} / \mathrm{mL})$. The results are expressed as mean (milligrams of catechin equivalent per gram of fresh matter).

\section{Determination of flavone and flavonol content}

An aliquot $(2 \mathrm{~mL})$ of the test solution, $20 \mathrm{~mL}$ methanol and $1 \mathrm{~mL} 5 \%$ aluminium chloride in methanol (w/v) were mixed in a volumetric flask and the volume was made up to $50 \mathrm{~mL}$ with methanol. The mixture was left for $30 \mathrm{~min}$ and the absorbance was measured at $425 \mathrm{~nm}$ (Bonvehi et al., 1994).

\section{Analysis by HPLC}

Anthocyanins and phenols were analysed using the highperformance liquid chromatography (HPLC) method. The identification was based on comparing retention times and on-line spectral data in comparison with original standards. The quantification was performed using the calibration curves of each standard compounds. The concentration was estimated from a calibration curves, constructed by plotting known solutions $(1.25-20 \mu \mathrm{g} / \mathrm{mL})$. The results were expressed as mean (milligrams of catechin equivalent per gram of dry matter).

The analyses were performed using an HPLC Shimadzu Nexera comprising a gradient pump, Shimadzu Nexera X2, a ProStar model 410 AutoSampler, a ProStar model 330 Photodiode Array Detector was performed on a reversedphase Waters C18 x select $(250 \mathrm{~mm} \times 4.6 \mathrm{~mm}, 5 \mathrm{~mm})$ at a temperature of $25^{\circ} \mathrm{C}$.

\section{HPLC analysis of anthocyanins}

For the measurement of anthocyanins with HPLC, 1 $\mathrm{mL}$ of the supernatant was evaporated with a sample concentrator at room temperature under a stream of nitrogen gas and the pellet was dissolved in $20 \mathrm{~mL}$ of $50 \%$ methanol in water.

Anthocyanins (cyanidin-3-O- glucoside, delphinidin-3$\mathrm{O}-$ glucoside, petunidin-3-O- glucoside, peonidin-3-Oglucoside, malvidin-3-O- glucoside), monomeric and dimeric phenols $[(+)$-catechin, (-)-epicatechin, proanthocyanidin B1 and B2, gallic acid, protocatechuic acid, caftaric acid, vanillic acid, caffeic acid, coutaric acid, vanillin, syringic acid, fertaric acid, p-coumaric, m-coumaric, piceid, ferulic acid, sinapic acid, rutin, trans-resveratrol, $\varepsilon$-viniferin, quercetin, luteolin)] were determined by HPLC-DAD system (Shimadzu Nexera).

For the separation of monomeric anthocyanins, a $250 \times 4.6 \mathrm{~mm}$ i.d., $5 \mu \mathrm{m}$, Waters $\mathrm{x}$ select C18 column operating at $30^{\circ} \mathrm{C}$ was employed. The eluent was composed of (A) $\mathrm{H}_{2} \mathrm{O} / \mathrm{HCOOH}(90: 10)$ and (B) $\mathrm{CH}_{3} \mathrm{OH}(100)$, and the flow rate was $1 \mathrm{~mL} / \mathrm{min}$. The following linear gradient program was used for the elution: $5 \% \mathrm{~B}$ for $0 \mathrm{~min}$, from $5 \%$ to $50 \%$ B in $25 \mathrm{~min}$, from $50 \%$ to $95 \%$ B in 30 $\mathrm{min}$, followed by a return to the initial conditions in $10 \mathrm{~min}$ and re-equilibration of the column. The chromatogram was monitored at $520 \mathrm{~nm}$.

HPLC analysis of individual phenols

For the measurement of individual phenols with HPLC, liquid extraction took place; $0.5 \mathrm{~mL}$ extract was mixed up 
100

with $4 \mathrm{~mL}$ ethyl acetate with vortex and the supernatant was separated. The supernatant was washed 2 times with distilled water. Finally, the supernatants were evaporated with a sample concentrator and the pellets were dissolved in $1 \mathrm{~mL}$ of $50 \%$ methanol. Finally, $1.5 \mathrm{~mL}$ was filtered through a $0.22 \mu \mathrm{m}$ membrane before the HPLC analysis.

For the separation of monomeric and dimeric phenols, a $250 \times 4.6 \mathrm{~mm}$ ID, $5 \mu \mathrm{m}$, Waters $\mathrm{x}$ select $\mathrm{C} 18$ column operating at $30^{\circ} \mathrm{C}$ was employed. The eluent was composed of (A) $\mathrm{H}_{2} \mathrm{O} / \mathrm{HClO}_{4}$ (99:1) and (B) $\mathrm{CH}_{3} \mathrm{OH}$ (100), and the flow rate was $0.5 \mathrm{~mL} / \mathrm{min}$. The following linear gradient program was used for the elution: $0 \% \mathrm{~B}$ for $2 \mathrm{~min}$, from $0 \%$ to $5 \% \mathrm{~B}$ in $16 \mathrm{~min}$, from $5 \%$ to $10 \% \mathrm{~B}$ in $25 \mathrm{~min}$, from $10 \%$ to $15 \% \mathrm{~B}$ in $50 \mathrm{~min}$, from $15 \%$ to $25 \% \mathrm{~B}$ in $90 \mathrm{~min}$, from $25 \%$ to $45 \%$ B in $120 \mathrm{~min}$, from $45 \%$ to $75 \%$ B in $145 \mathrm{~min}$, from $75 \%$ to $90 \%$ B in $150 \mathrm{~min}$, from $90 \%$ to $95 \%$ B in 155 $\mathrm{min}$, followed by a return to the initial conditions in $10 \mathrm{~min}$ and re-equilibration of the column. The chromatogram was monitored at 280, 320, and $360 \mathrm{~nm}$.

\section{Data analysis}

All results were expressed as mean \pm SE (Standard Error) of the three (3) replications out of three (3) samples/bunches (i.e. the three bunches were considered as one replication). All determinations were analysed in triplicate. Data were processed by analysis of Variance (ANOVA) and the statistical significance was processed using the Student's test at $\mathrm{P} \geq 0.05$. All statistical analysis and correlations were obtained using JMP v. 10 statistical software (SAS Institute Inc., Cary, NC, USA).

\section{Results}

The results (mean value and standard error) obtained for the skins and seeds of the studied grapevine varieties are shown in Tables 2, 3, 4, 5, and 6. Statistically significant differences were found between the studied varieties and for each compound analysed. These differences were highlighted with different super indexes.

\section{Grape mechanical properties and characters of the must}

The grapevine variety 'Bekari' presented the highest length of the bunch $(23 \mathrm{~cm})$, with statistically significant difference compared to the other varieties, whose bunch length ranged from $17.3 \mathrm{~cm}$ to $15.8 \mathrm{~cm}$. The grapevine varieties 'Thrapsa' and 'Doubrena mavri' presented the highest width and weight of the bunch, with no statistically significant difference between them. The grapevine variety 'Kolliniatiko' showed the highest concentration of total soluble solids and of $\mathrm{pH}\left(23.1^{\circ} \mathrm{Brix}\right.$ and 3.86 respectively). The highest value in total acidity was recorded in the grapevine variety 'Kountoura mavri' (7.5 g tartaric acid/L), with statistically significant difference compared to the other grapevine varieties (Table 2).

\section{Polyphenols in berry skin and seeds}

The results of ANOVA presented in Table 3 show that the berry skins of grapevine variety 'Mavro Spetson' presented (a) the highest concentration of total phenolics and total flavonoids, with no statistically significant difference compared to 'Kountoura mavri'; and (b) the highest concentration of condensed tannins, with no statistically significant difference compared to 'Bekari'. It should be noted that the condensed tannins (or proanthocyanidins) derived from grapes that are of most interest in enology and viticulture. Information regarding viticultural impacts on tannin biosynthesis, concentration and composition is of critical importance to improve the understanding of astringency, mouth-feel and colour attributes of red wine (Sarneckis et al., 2006). Furthermore, the grapevine varieties of the present study exhibited higher concentration of condensed tannins, compared to other grapevine varieties, such as 'Cabernet Sauvignon', 'Merlot' and others (Seddon and Downey 2008).

The grapevine variety 'Kountoura mavri' presented the highest value regarding the seed total flavonoids concentration, as well as the highest concentration of total phenolics and condensed tannins, with no statistically significant difference compared to 'Mavro Spetson'.

The berry skin of all studied varieties contained the five basic anthocyanins (cyanidin 3-O-glucoside, delphinidin 3O-glucoside, petunidin 3-O-glucoside, peonidin 3-Oglucoside, malvidin 3-O-glucoside) (Table 4). It should be noted that the one of the main class of phenolic compounds in grapes, from a red wine quality perspective, are the anthocyanins (Lorrain et al., 2011).

The grapevine variety 'Kolliniatiko' exhibited the highest concentration of total anthocyanins as well as of all individual anthocyanins (except for peonidin). In fact, it

Table 2. Grape mechanical properties and characters of the must (mean \pm SE)

\begin{tabular}{|c|c|c|c|c|c|c|c|}
\hline Trait & Kolliniatiko & Bekari & Bakouri & Kountoura mavri & Doubrena mavri & Thrapsa & $\begin{array}{l}\text { Mavro } \\
\text { Spetson }\end{array}$ \\
\hline $\begin{array}{c}\text { Total soluble solids } \\
\text { ('Brix) }\end{array}$ & $23.1 \pm 0.06 \mathrm{a}$ & $21.3 \pm 0.03 \mathrm{~b}$ & $18.6 \pm 0.06 \mathrm{c}$ & $15.6 \pm 0.06 \mathrm{e}$ & $16.0 \pm 0.01 \mathrm{~d}$ & $14.9 \pm 0.06 \mathrm{f}$ & $13.8 \pm 0.03 \mathrm{~g}$ \\
\hline $\mathrm{pH}$ & $3.86 \pm 0.003 \mathrm{a}$ & $3.83 \pm 0.006 \mathrm{~b}$ & $3.63 \pm 0.003 \mathrm{c}$ & $3.11 \pm 0.006 \mathrm{~g}$ & $3.47 \pm 0.001 \mathrm{e}$ & $3.39 \pm 0.008 \mathrm{f}$ & $3.59 \pm 0.003 \mathrm{~d}$ \\
\hline $\begin{array}{c}\text { Total acidity (gr } \\
\text { tartaric acid/ L must) }\end{array}$ & $5.25 \pm 0.217 \mathrm{c}$ & $3.75 \pm 0.127 \mathrm{e}$ & $6.0 \pm 0.09 \mathrm{~b}$ & $7.5 \pm 0.217 \mathrm{a}$ & $4.5 \pm 0.127 \mathrm{~d}$ & $5.25 \pm 0.172 \mathrm{c}$ & $3.5 \pm 0.172 \mathrm{e}$ \\
\hline Length of grapes $(\mathrm{cm})$ & $16.2 \pm 0.4 b$ & $23.0 \pm 1.7 \mathrm{a}$ & $16.5 \pm 0.9 \mathrm{~b}$ & $17.3 \pm 0.3 \mathrm{~b}$ & $16.5 \pm 0.9 \mathrm{~b}$ & $17.3 \pm 1.8 \mathrm{~b}$ & $15.8 \pm 2.1 \mathrm{~b}$ \\
\hline Width of grapes $(\mathrm{cm})$ & $8.2 \pm 0.3 \mathrm{~d}$ & $8.8 \pm 0.7 \mathrm{~d}$ & $11.5 \pm 0.9 \mathrm{bc}$ & $11.7 \pm 0.3 \mathrm{bc}$ & $12.3 \pm 0.4 \mathrm{ab}$ & $14.3 \pm 0.6 \mathrm{a}$ & $9.5 \pm 1.3 \mathrm{~cd}$ \\
\hline $\begin{array}{l}\text { Weight of } \\
\text { grapes }(\mathrm{g})\end{array}$ & $120.0 \pm 10.0 \mathrm{c}$ & $216.0 \pm 48.8 \mathrm{bc}$ & $274.7 \pm 21.7 \mathrm{~b}$ & $227.0 \pm 5.1 \mathrm{bc}$ & $309.7 \pm 29.2 \mathrm{ab}$ & $425.3 \pm 89.4 \mathrm{a}$ & $221.3 \pm 37.1 \mathrm{bc}$ \\
\hline
\end{tabular}


Table 3. Berry skin and seeds total phenolics, total flavonoids and condensed tannins (mean \pm SE)

\begin{tabular}{|c|c|c|c|c|c|c|c|c|}
\hline \multicolumn{2}{|c|}{ Element (content)/Cultivar } & Kolliniatiko & Bekari & Bakouri & Kountoura & Doubrena mavri & Thrapsa & Mavro Spetson \\
\hline \multirow{2}{*}{ Total phenolics } & $\begin{array}{l}\text { Skin (mg } \\
\text { gallic acid / } \\
\text { gr fresh } \\
\text { tissue) }\end{array}$ & $\begin{array}{c}7.38 \pm 0.720 \\
\text { c }\end{array}$ & $\begin{array}{c}10.72 \pm 0.652 \\
b\end{array}$ & $\begin{array}{c}4.97 \pm 0.299 \\
\mathrm{~d}\end{array}$ & $\begin{array}{c}9.16 \pm 0.732 \\
\text { bc }\end{array}$ & $\begin{array}{c}4.40 \pm 0.475 \\
\mathrm{~d}\end{array}$ & $\begin{array}{c}7.83 \pm 1.029 \\
\text { c }\end{array}$ & $\begin{array}{c}16.19 \pm 0.724 \\
\mathrm{a}\end{array}$ \\
\hline & $\begin{array}{c}\text { Seeds (mg } \\
\text { gallic acid / } \\
\text { gr fresh } \\
\text { tissue) }\end{array}$ & $\begin{array}{c}23.86 \pm 1.835 \\
\mathrm{~d}\end{array}$ & $\begin{array}{c}23.53 \pm 2.240 \\
\mathrm{~d}\end{array}$ & $\begin{array}{c}26.36 \pm 1.568 \\
\mathrm{~cd}\end{array}$ & $\begin{array}{c}40.30 \pm 1.348 \\
\mathrm{a}\end{array}$ & $\begin{array}{c}27.76 \pm 1.197 \\
\mathrm{~cd}\end{array}$ & $\begin{array}{c}31.99 \pm 1.873 \\
\text { bc }\end{array}$ & $\begin{array}{c}39.23 \pm 5.054 \\
\mathrm{ab}\end{array}$ \\
\hline \multirow{2}{*}{$\begin{array}{c}\text { Total } \\
\text { flavonoids }\end{array}$} & $\begin{array}{c}\text { Skin (mg } \\
\text { catechin/gr } \\
\text { fresh tissue) }\end{array}$ & $\begin{array}{c}10.66 \pm 0.414 \\
\mathrm{~cd}\end{array}$ & $\begin{array}{c}14.56 \pm 0.184 \\
\text { bc }\end{array}$ & $\begin{array}{c}8.64 \pm 0.288 \\
\text { d }\end{array}$ & $\begin{array}{c}17.45 \pm 3.172 \\
\mathrm{ab}\end{array}$ & $\begin{array}{c}13.08 \pm 0.279 \\
\text { bcd }\end{array}$ & $\begin{array}{c}15.13 \pm 0.933 \\
\text { bc }\end{array}$ & $\begin{array}{c}20.98 \pm 2.901 \\
\mathrm{a}\end{array}$ \\
\hline & $\begin{array}{l}\text { Seeds (mg } \\
\text { catechin/gr } \\
\text { fresh tissue) }\end{array}$ & $\begin{array}{c}44.48 \pm 0.890 \\
\mathrm{~d}\end{array}$ & $\begin{array}{c}46.46 \pm 3.407 \\
\text { d }\end{array}$ & $\begin{array}{c}50.11 \pm 1.746 \\
\mathrm{~d}\end{array}$ & $\begin{array}{c}88.70 \pm 1.387 \\
\text { a }\end{array}$ & $\begin{array}{c}63.03 \pm 3.040 \\
\mathrm{c}\end{array}$ & $\begin{array}{c}66.19 \pm 0.278 \\
\text { c }\end{array}$ & $\begin{array}{c}74.07 \pm 1.288 \\
\text { b }\end{array}$ \\
\hline \multirow{2}{*}{$\begin{array}{l}\text { Condensed } \\
\text { tannins }\end{array}$} & $\begin{array}{c}\text { Skin (mg } \\
\text { catechin/gr } \\
\text { fresh tissue) }\end{array}$ & $\begin{array}{c}19.23 \pm \\
1.606 \\
c\end{array}$ & $\begin{array}{c}41.70 \pm 1.016 \\
\mathrm{a}\end{array}$ & $\begin{array}{c}17.96 \pm 0.496 \\
\text { c }\end{array}$ & $\begin{array}{c}31.04 \pm 0.655 \\
\text { b }\end{array}$ & $\begin{array}{c}18.16 \pm 1.039 \\
\text { c }\end{array}$ & $\begin{array}{c}31.69 \pm 3.930 \\
b\end{array}$ & $\begin{array}{c}45.30 \pm 2.363 \\
\mathrm{a}\end{array}$ \\
\hline & $\begin{array}{l}\text { Seeds (mg } \\
\text { catechin/gr } \\
\text { fresh tissue) }\end{array}$ & $\begin{array}{c}72.74 \pm \\
1.242 \\
\text { c }\end{array}$ & $\begin{array}{c}112.73 \pm 3.692 \\
\text { b }\end{array}$ & $\begin{array}{c}98.89 \pm 3.417 \\
b\end{array}$ & $\begin{array}{c}151.96 \pm 3.573 \\
a\end{array}$ & $\begin{array}{c}97.68 \pm 4.136 \\
\text { b }\end{array}$ & $\begin{array}{c}109.39 \pm 10.226 \\
\text { b }\end{array}$ & $\begin{array}{c}145.85 \pm 3.858 \\
\mathrm{a}\end{array}$ \\
\hline
\end{tabular}

was 'Bekari' which showed the highest concentration of peonidin, with statistically significant difference compared to all other studied varieties. The grapevine varieties 'Kountoura mavri' and 'Doubrena mavri' presented high concentration of malvidin, without statistically significant difference compared to 'Kolliniatiko'. Based on the above results, malvidin seems to be the dominant anthocyanin, something which is in agreement with previous studies (Boss and Davies 2009; Chiou et al., 2014).

The ANOVA results (Table 5) have shown, that in general, the monomers (+)-catechin and (-)-epicatechin were the most abundant, assayed in concentrations in the berry skins ranging from $43,42 \mu \mathrm{g} / \mathrm{g}$ to $159.40 \mu \mathrm{g} / \mathrm{g}$ and 17,04 to $46,68 \mu \mathrm{g} / \mathrm{g}$ fresh tissue respectively. These results correlate well with previous findings on different Greek Vitis vinifera varieties ( 9.58 to $22.40 \mathrm{mg} / 100 \mathrm{~g}$ and 3.94 to $13.53 \mathrm{mg} / 100 \mathrm{~g}$ ) (Sakkiadi et al., 2007; Anastasiadi et al., 2010).

The grapevine variety 'Mavro Spetson' presented the highest concentration of berry skin catechin, procyanidin B1 and total flavanols. The grapevine variety 'Doubrena mavri' showed (a) the highest concentration of epicatechin with no statistically significant difference compared to 'Mavro Spetson', and (b) the highest concentration of procyanidin B2, with no statistically significant difference compared to the other studied varieties.

Grapevine variety 'Bakouri' presented the highest concentration of seed total flavanols, with no statistically significant difference compared to 'Kountoura mavri'.

From the overall results, it is confirmed that the seeds of all studied varieties have higher concentration of flavanols compared to the skin, something that is in agreement with previous reports (Makris et al., 2006; Ribereau-Gayon et al., 2006; Stavrakakis, 2013).
Regarding the berry skin flavonol content, the highest concentrations of luteolin, quercetin, and rutin were recorded in grapevine varieties 'Doubrena mavri', 'Mavro Spetson' and 'Bekari' respectively. No statistically significant difference between grapevine varieties 'Mavro Spetson' emerged regarding the quercetin concentration. The grapevine variety 'Bekari' exhibited the highest concentration of berry skin total flavonols and flavones with no statistically significant difference compared to 'Kolliniatiko'.

Regarding the seed total flavonols and flavones, the highest concentration was recorded in grapevine variety 'Kountoura mavri', with no statistically significant difference compared to 'Bakouri' and 'Mavro Spetson'.

Were we to compare the grapevine varieties of the present study with other related studies, it appears that they are all characterized by high concentrations of flavonols and flavones, especially luteolin and rutin. (Iacopini et al., 2008; Anastasiadi et al., 2010).

In addition, it was also found that the concentration of total flavonols and flavones is higher in the skins than in the seeds (Makris et al., 2006; Ribereau-Gayon et al., 2006; Stavrakakis, 2013).

\section{Hydroxybenzoic acids}

The grapevine variety 'Doubrena mavri' presented the highest concentration of gallic acid, with no statistically significant difference to 'Kolliniatiko' (Table 6). At the same time, 'Thrapsa' showed the highest concentration of protocatechuic acid, with no statistically significant difference compared to 'Doubrena mavri', 'Bekari' and 'Kontoura mavri'. The grapevine variety 'Bakouri' showed the highest concentration of vanillic acid compared to 'Doubrena mavri' and 'Bekari', while it also presented the 
102

Table 4. Berry skin individual and total anthocyanins $($ mean \pm SE)

\begin{tabular}{|c|c|c|c|c|c|c|c|c|}
\hline \multicolumn{2}{|c|}{ Element (content)/Cultivar } & Kolliniatiko & Bekari & Bakouri & $\begin{array}{c}\text { Kountoura } \\
\text { mavri }\end{array}$ & $\begin{array}{c}\text { Doubrena } \\
\text { mavri }\end{array}$ & Thrapsa & $\begin{array}{l}\text { Mavro } \\
\text { Spetson }\end{array}$ \\
\hline \multirow{5}{*}{$\begin{array}{c}\text { Individual } \\
\text { anthocyanins }\end{array}$} & $\begin{array}{l}\text { Cyanidin 3-O- } \\
\text { glucoside (mg/ } \\
\text { gr fresh tissue) }\end{array}$ & $\begin{array}{c}0.051 \pm 0.002 \\
\mathrm{a}\end{array}$ & $\begin{array}{c}0.042 \pm 0.002 \\
\mathrm{~b}\end{array}$ & $\begin{array}{c}0.007 \pm 0.002 \\
\text { cd }\end{array}$ & $\begin{array}{c}0.007 \pm 0.001 \\
\text { cd }\end{array}$ & $\begin{array}{c}0.007 \pm 0.001 \\
\text { cd }\end{array}$ & $\begin{array}{c}0.013 \pm 0.001 \\
\text { c }\end{array}$ & $\begin{array}{c}0.007 \pm 0.005 \\
\mathrm{~d}\end{array}$ \\
\hline & $\begin{array}{l}\text { Delphinidin 3- } \\
\text { O-glucoside (mg } \\
\text { / gr fresh tissue) }\end{array}$ & $\begin{array}{c}0.386 \pm 0.017 \\
\mathrm{a}\end{array}$ & $\begin{array}{c}0.064 \pm 0.004 \\
\mathrm{~b}\end{array}$ & $\begin{array}{c}0.029 \pm 0.006 \\
\text { c }\end{array}$ & $\begin{array}{c}0.063 \pm 0.004 \\
\mathrm{~b}\end{array}$ & $\begin{array}{c}0.059 \pm 0.004 \\
\mathrm{~b}\end{array}$ & $\begin{array}{c}0.019 \pm 0.002 \\
\text { c }\end{array}$ & $\begin{array}{c}0.023 \pm 0.008 \\
\text { c }\end{array}$ \\
\hline & $\begin{array}{l}\text { Petunidin 3-O- } \\
\text { glucoside (mg / } \\
\text { gr fresh tissue) }\end{array}$ & $\begin{array}{c}0.377 \pm 0.017 \\
\mathrm{a}\end{array}$ & $\begin{array}{c}0.095 \pm 0.005 \\
\mathrm{~b}\end{array}$ & $\begin{array}{c}0.045 \pm 0.007 \\
\text { c }\end{array}$ & $\begin{array}{c}0.096 \pm 0.006 \\
b\end{array}$ & $\begin{array}{c}0.094 \pm 0.006 \\
\mathrm{~b}\end{array}$ & $\begin{array}{c}0.032 \pm 0.003 \\
\text { c }\end{array}$ & $\begin{array}{c}0.038 \pm 0.010 \\
\text { c }\end{array}$ \\
\hline & $\begin{array}{l}\text { Peonidin 3-O- } \\
\text { glucoside (mg / } \\
\text { gr fresh tissue) }\end{array}$ & $\begin{array}{c}0.045 \pm 0.002 \\
\mathrm{~b}\end{array}$ & $\begin{array}{c}0.095 \pm 0.004 \\
\mathrm{a}\end{array}$ & $\begin{array}{c}0.029 \pm 0.009 \\
\text { bc }\end{array}$ & $\begin{array}{c}0.035 \pm 0.002 \\
\text { bc }\end{array}$ & $\begin{array}{c}0.029 \pm 0.002 \\
\text { bc }\end{array}$ & $\begin{array}{c}0.023 \pm 0.001 \\
\mathrm{c}\end{array}$ & $\begin{array}{c}0.020 \pm 0.011 \\
\text { c }\end{array}$ \\
\hline & $\begin{array}{l}\text { Malvidin 3-O- } \\
\text { glucoside (mg/ } \\
\text { gr fresh tissue) }\end{array}$ & $\begin{array}{c}0.890 \pm 0.042 \\
\mathrm{a}\end{array}$ & $\begin{array}{c}0.604 \pm 0.025 \\
\text { bc }\end{array}$ & $\begin{array}{c}0.591 \pm 0.112 \\
\text { c }\end{array}$ & $\begin{array}{c}0.893 \pm 0.042 \\
\text { a }\end{array}$ & $\begin{array}{c}0.841 \pm 0.041 \\
\mathrm{ab}\end{array}$ & $\begin{array}{c}0.379 \pm 0.033 \\
\text { c }\end{array}$ & $\begin{array}{c}0.479 \pm 0.168 \\
\text { c }\end{array}$ \\
\hline $\begin{array}{c}\text { Total } \\
\text { anthocyanins }\end{array}$ & $\begin{array}{l}\text { Skin (mg } \\
\text { malvidin 3-O- } \\
\text { glucoside/ gr } \\
\text { fresh tissue) }\end{array}$ & $\begin{array}{c}15.54 \pm 0.981 \\
\mathrm{a}\end{array}$ & $\begin{array}{c}11.85 \pm 0.159 \\
b\end{array}$ & $\begin{array}{c}10.11 \pm \\
0.417 \\
\text { c }\end{array}$ & $\begin{array}{c}10.02 \pm 0.520 \\
\text { c }\end{array}$ & $\begin{array}{c}9.90 \pm 0.275 \\
\mathrm{c}\end{array}$ & $\begin{array}{c}7.95 \pm 0.523 \\
\mathrm{~d}\end{array}$ & $\begin{array}{c}4.23 \pm 0.104 \\
\mathrm{e}\end{array}$ \\
\hline
\end{tabular}

Table 5. Individual flavanols and flavonols in berry skin and total flavanols, flavonols and flavones in berry skin and seeds (mean \pm SE)

\begin{tabular}{|c|c|c|c|c|c|c|c|c|}
\hline \multicolumn{2}{|c|}{ Element (content)/Cultivar } & Kolliniatiko & Bekari & Bakouri & $\begin{array}{c}\text { Kountoura } \\
\text { mavri }\end{array}$ & $\begin{array}{c}\text { Doubrena } \\
\text { mavri }\end{array}$ & Thrapsa & $\begin{array}{l}\text { Mavro } \\
\text { Spetson }\end{array}$ \\
\hline \multirow{4}{*}{$\begin{array}{l}\text { Individual } \\
\text { flavanols }\end{array}$} & $\begin{array}{c}\text { Catechin ( } \mu \mathrm{g} \\
\text { / gr fresh } \\
\text { tissue) }\end{array}$ & $\begin{array}{c}43.42 \pm 3.752 \\
\mathrm{~d}\end{array}$ & $\begin{array}{c}68.04 \pm 2.452 \\
\text { bc }\end{array}$ & $\begin{array}{c}52.92 \pm 3.208 \\
\text { bcd }\end{array}$ & $\begin{array}{c}51.52 \pm 3.388 \\
\mathrm{~cd}\end{array}$ & $\begin{array}{c}69.28 \pm 4.258 \\
\mathrm{~b}\end{array}$ & $\begin{array}{c}62.44 \pm 4.988 \\
\text { bc }\end{array}$ & $\begin{array}{c}159.40 \pm 11.352 \\
\mathrm{a}\end{array}$ \\
\hline & $\begin{array}{l}\text { Epicatechin } \\
\text { ( } \mu \mathrm{g} / \mathrm{gr} \text { fresh } \\
\text { tissue })\end{array}$ & $\begin{array}{c}23.60 \pm 2.712 \\
b\end{array}$ & $\begin{array}{c}24.68 \pm 1.396 \\
b\end{array}$ & $\begin{array}{c}21.68 \pm 0.212 \\
b\end{array}$ & $\begin{array}{c}17.04 \pm 0.762 \\
b\end{array}$ & $\begin{array}{c}46.68 \pm 5.422 \\
a\end{array}$ & $\begin{array}{c}17.36 \pm 1.508 \\
b\end{array}$ & $\begin{array}{c}40.98 \pm 4.044 \\
\mathrm{a}\end{array}$ \\
\hline & $\begin{array}{l}\text { Procyanidin } \\
\mathrm{Bl}(\mu \mathrm{g} / \mathrm{gr} \\
\text { fresh tissue })\end{array}$ & $\begin{array}{c}4.20 \pm 1.784 \\
\text { bc }\end{array}$ & $\begin{array}{c}4.10 \pm 0.244 \\
\text { bc }\end{array}$ & $\begin{array}{c}6.10 \pm 0.200 \\
\text { bc }\end{array}$ & $\begin{array}{c}1.72 \pm 0.578 \\
\text { c }\end{array}$ & $\begin{array}{c}9.40 \pm 1.594 \\
b\end{array}$ & $\begin{array}{c}3.88 \pm 1.466 \\
\text { c }\end{array}$ & $\begin{array}{c}21.60 \pm 3.812 \\
\mathrm{a}\end{array}$ \\
\hline & $\begin{array}{c}\text { Procyanidin } \\
\text { B2 ( } \mu \mathrm{g} / \mathrm{gr} \\
\text { fresh tissue) }\end{array}$ & $\begin{array}{c}2.60 \pm 0.76 \\
\mathrm{~cd}\end{array}$ & $\begin{array}{c}5.24 \pm 2.42 \\
c\end{array}$ & $\begin{array}{c}8.92 \pm 0.72 \\
b\end{array}$ & $\begin{array}{c}1.36 \pm 0.16 \\
\mathrm{~d}\end{array}$ & $\begin{array}{c}15.24 \pm 1.22 \\
\mathrm{a}\end{array}$ & $\begin{array}{c}1.44 \pm 0.16 \\
\mathrm{~d}\end{array}$ & $\begin{array}{c}1.50 \pm 0.40 \\
\mathrm{~d}\end{array}$ \\
\hline \multirow{2}{*}{$\begin{array}{c}\text { Total } \\
\text { flavanols }\end{array}$} & $\begin{array}{c}\text { Skin (mg } \\
\text { catechin/gr } \\
\text { fresh tissue) }\end{array}$ & $\begin{array}{c}3.76 \pm 0.061 \\
\mathrm{~d}\end{array}$ & $\begin{array}{c}5.59 \pm 0.064 \\
\text { c }\end{array}$ & $\begin{array}{c}3.15 \pm 0.057 \\
\mathrm{~d}\end{array}$ & $\begin{array}{c}6.01 \pm 0.405 \\
b c\end{array}$ & $\begin{array}{c}5.86 \pm 0.262 \\
\text { bc }\end{array}$ & $\begin{array}{c}6.43 \pm 0.293 \\
b\end{array}$ & $\begin{array}{c}9.84 \pm 0.275 \\
a\end{array}$ \\
\hline & $\begin{array}{l}\text { Seeds }(\mathrm{mg} \\
\text { catechin/gr } \\
\text { fresh tissue) }\end{array}$ & $\begin{array}{c}19.60 \pm 0.590 \\
\mathrm{~d}\end{array}$ & $\begin{array}{c}20.89 \pm 1.329 \\
\mathrm{~cd}\end{array}$ & $\begin{array}{c}43.48 \pm 4.198 \\
\mathrm{a}\end{array}$ & $\begin{array}{c}37.66 \pm 0.845 \\
\mathrm{a}\end{array}$ & $\begin{array}{c}29.09 \pm 1.226 \\
b\end{array}$ & $\begin{array}{c}30.82 \pm 1.697 \\
\mathrm{~b}\end{array}$ & $\begin{array}{c}25.48 \pm 1.011 \\
\text { bc }\end{array}$ \\
\hline \multirow{3}{*}{$\begin{array}{l}\text { Individual } \\
\text { flavonols }\end{array}$} & $\begin{array}{c}\text { Luteoline ( } \mu \mathrm{g} \\
\text { /gr fresh } \\
\text { tissue) }\end{array}$ & $\begin{array}{c}843.62 \pm 157.672 \\
\text { d }\end{array}$ & $\begin{array}{c}1290.96 \pm 9.450 \\
\text { b }\end{array}$ & $\begin{array}{c}1059.66 \pm 2.162 \\
\mathrm{~cd}\end{array}$ & $\begin{array}{c}1081.92 \pm 13.356 \\
\text { bc }\end{array}$ & $\begin{array}{c}1979.94 \pm 34.166 \\
a\end{array}$ & $\begin{array}{c}1003.28 \pm 96.498 \\
\text { cd }\end{array}$ & $\begin{array}{c}879.64 \pm 38.760 \\
\text { cd }\end{array}$ \\
\hline & $\begin{array}{c}\text { Quercetin ( } \mu \mathrm{g} \\
\text { /gr fresh } \\
\text { tissue) }\end{array}$ & $\begin{array}{c}29.90 \pm 3.846 \\
\text { bcd }\end{array}$ & $\begin{array}{c}40.70 \pm 5.096 \\
\text { bc }\end{array}$ & $\begin{array}{c}25.22 \pm 0.064 \\
\mathrm{~cd}\end{array}$ & $\begin{array}{c}23.48 \pm 0.332 \\
\mathrm{~d}\end{array}$ & $\begin{array}{c}42.02 \pm 0.718 \\
\mathrm{ab}\end{array}$ & $\begin{array}{c}21.92 \pm 0.316 \\
\mathrm{~d}\end{array}$ & $\begin{array}{c}56.92 \pm 12.184 \\
\mathrm{a}\end{array}$ \\
\hline & $\begin{array}{l}\text { Rutin }(\mu \mathrm{g} / \mathrm{gr} \\
\text { fresh tissue) }\end{array}$ & $\begin{array}{c}705.02 \pm 84.548 \\
\text { c }\end{array}$ & $\begin{array}{c}1328.24 \pm 8.598 \\
\mathrm{a}\end{array}$ & $\begin{array}{c}612.54 \pm 6.606 \\
\mathrm{~cd}\end{array}$ & $\begin{array}{c}361.54 \pm 5.544 \\
\mathrm{e}\end{array}$ & $\begin{array}{c}901.3 \pm 25.466 \\
b\end{array}$ & $\begin{array}{c}512.44 \pm 37.926 \\
\mathrm{~d}\end{array}$ & $\begin{array}{c}632.42 \pm 46.806 \\
\text { cd }\end{array}$ \\
\hline \multirow{2}{*}{$\begin{array}{c}\text { Total } \\
\text { flavonols } \\
\& \\
\text { flavones }\end{array}$} & $\begin{array}{c}\text { Skin (mg } \\
\text { rutin / gr } \\
\text { fresh tissue) }\end{array}$ & $\begin{array}{c}2.97 \pm 0.106 \\
\mathrm{a}\end{array}$ & $\begin{array}{c}3.20 \pm 0.070 \\
\mathrm{a}\end{array}$ & $\begin{array}{c}2.17 \pm 0.036 \\
b\end{array}$ & $\begin{array}{c}2.17 \pm 0.170 \\
b\end{array}$ & $\begin{array}{c}2.26 \pm 0.062 \\
b\end{array}$ & $\begin{array}{c}1.82 \pm 0.106 \\
\text { c }\end{array}$ & $\begin{array}{c}1.68 \pm 0.129 \\
\text { c }\end{array}$ \\
\hline & $\begin{array}{l}\text { Seeds (mg } \\
\text { rutin / gr } \\
\text { fresh tissue) }\end{array}$ & $\begin{array}{c}0.44 \pm 0.004 \\
\mathrm{~d}\end{array}$ & $\begin{array}{c}0.58 \pm 0.011 \\
\mathrm{~b}\end{array}$ & $\begin{array}{c}0.62 \pm 0.044 \\
\mathrm{ab}\end{array}$ & $\begin{array}{c}0.67 \pm 0.028 \\
a\end{array}$ & $\begin{array}{c}0.56 \pm 0.017 \\
\text { bc }\end{array}$ & $\begin{array}{c}0.49 \pm 0.025 \\
\text { cd }\end{array}$ & $\begin{array}{c}0.61 \pm 0.035 \\
\mathrm{ab}\end{array}$ \\
\hline
\end{tabular}


highest concentration of syringic acid, with statistically significant difference compared to all studied varieties. It should be noted, that the concentration of gallic acid in the skins of the studied varieties ranged at the same level compared to other Greek grapevine varieties ('Agiorgitiko', 'Mandilaria') of related studies (Anastasiadi et al., 2010; Tsaparas, 2013).

\section{Hydroxycinnamic acids}

The highest concentrations in berry skin of sinapic acid and caffeic acid were recorded in grapevine varieties 'Bekari' and 'Kolliniatiko', respectively (Table 6). The highest concentration of p-coumaric acid was recorded in the case of grapevine variety 'Mavro Spetson', with no statistically significant difference compared to 'Kolliniatiko', 'Bekari', 'Kountoura mavri' and 'Bakouri'. Regarding the $\mathrm{m}$ coumaric acid, the highest concentration was recorded in the case of grapevine variety 'Bekari', with no statistically significant difference compared to 'Kolliniatiko' and 'Doubrena mavri'. The grapevine variety 'Thrapsa' showed the lowest concentration of ferulic acid, with statistically significant difference compared to the other studied varieties, which in their turn had no statistically significant difference between them.
The grapevine varieties 'Kolliniatiko' and 'Doubrena mavri' presented the highest concentration of caftaric acid, with statistically significant difference compared to the other studied varieties. At the same time, 'Doubrena mavri' showed the highest concentration of coutaric acid, with no statistically significant difference compared to "Mavro Spetson' and 'Kolliniatiko'. On the other hand, it was 'Mavro Spetson' that presented the highest concentration of fertaric acid, with statistically significant difference between the studied varieties.

The above results show that caftaric acid outweighs coutaric and fertaric acids, something that is in agreement with the findings of a previous study (Di Stefano and Flamini, 2008).

\section{Stilbenes and phenolic aldehyde}

Regarding the stilbene skin content, the grapevine varieties 'Kolliniatiko' and 'Bekari' presented the highest concentration of trans-resveratrol and piceid, with statistically significant difference compared to all other studied varieties (Table 6). What is more, the grapevine variety 'Kolliniatiko' also exhibited the highest concentration of $\varepsilon$-viniferin, with statistically significant difference compared to the other studied varieties.

Table 6. Hydroxybenzoic and hydroxycinnamic acids, stilbenes and phenolic aldehyde (mean $\pm \mathrm{SE}$ )

\begin{tabular}{|c|c|c|c|c|c|c|c|c|}
\hline \multicolumn{2}{|c|}{ Element (content)/Cultivar } & \multirow{2}{*}{$\begin{array}{l}\text { Kolliniatiko } \\
2.02 \pm 0.720\end{array}$} & \multirow{2}{*}{$\begin{array}{c}\text { Bekari } \\
0.34 \pm 0.062\end{array}$} & \multirow{2}{*}{$\begin{array}{c}\text { Bakouri } \\
0.20 \pm 0.050\end{array}$} & \multirow{2}{*}{$\begin{array}{c}\begin{array}{c}\text { Kountoura } \\
\text { mavri }\end{array} \\
0.20 \pm 0.074\end{array}$} & $\begin{array}{c}\text { Doubrena } \\
\text { mavri }\end{array}$ & Thrapsa & \multirow{2}{*}{$\begin{array}{c}\begin{array}{c}\text { Mavro } \\
\text { Spetson }\end{array} \\
0.16 \pm 0.048\end{array}$} \\
\hline \multirow{8}{*}{$\begin{array}{c}\text { Hydroxybenzoic } \\
\text { acids }\end{array}$} & Gallic acid $(\mu \mathrm{g} / \mathrm{gr}$ & & & & & $2.48 \pm 0.604$ & $0.20 \pm 0.040$ & \\
\hline & fresh tissue) & a & $\mathrm{b}$ & b & $\mathrm{b}$ & a & $\mathrm{b}$ & $\mathrm{b}$ \\
\hline & Protocatechuic acid & $0.12 \pm 0.006$ & $0.18 \pm 0.004$ & $0.12 \pm 0.006$ & $0.14 \pm 0.054$ & $0.20 \pm 0.018$ & $0.22 \pm 0.064$ & $0.12 \pm 0.022$ \\
\hline & ( $\mu \mathrm{g} / \mathrm{gr}$ fresh tissue) & $\mathrm{b}$ & $\mathrm{ab}$ & $\mathrm{b}$ & $\mathrm{ab}$ & $\mathrm{ab}$ & a & $\mathrm{b}$ \\
\hline & Vanillic acid ( $\mu \mathrm{g} /$ & $0.44 \pm 0.214$ & $1.28 \pm 0.588$ & $2.16 \pm 0.144$ & $1.10 \pm 0.414$ & $1.52 \pm 0.070$ & $0.38 \pm 0.082$ & $0.18 \pm 0.022$ \\
\hline & gr fresh tissue) & cde & $a b c$ & a & bcd & $a b$ & de & e \\
\hline & Syringic acid ( $\mu g$ / & $4.22 \pm 0.40$ & $4.16 \pm 0.60$ & $8.68 \pm 0.16$ & $4.92 \pm 0.44$ & $6.28 \pm 0.50$ & $4.30 \pm 0.22$ & $5.70 \pm 0.84$ \\
\hline & gr fresh tissue) & $\mathrm{cd}$ & $\mathrm{d}$ & $\mathrm{a}$ & bcd & $\mathrm{b}$ & $\mathrm{cd}$ & $\mathrm{bc}$ \\
\hline \multirow{16}{*}{$\begin{array}{l}\text { Hydroxycinnamic } \\
\text { acids }\end{array}$} & Sinapic acid ( $\mu \mathrm{g} / \mathrm{gr}$ & $39.48 \pm 12.590$ & $56.16 \pm 5.54$ & $25.68 \pm 7.548$ & $31.40 \pm 4.502$ & $37.24 c \pm 0.964$ & $18.32 \pm 0.714$ & $44.68 \pm 12.702$ \\
\hline & fresh tissue) & $\mathrm{abc}$ & a & bc & bc & $\mathrm{ab}$ & c & $\mathrm{ab}$ \\
\hline & Caffeic acid ( $\mu g / g r$ & $14.12 \pm 2.538$ & $4.94 \pm 0.050$ & $8.96 \pm 0.008$ & $1.40 \pm 0.036$ & $7.84 \pm 0.188$ & $1.56 \pm 0.122$ & $3.08 \pm 0.510$ \\
\hline & fresh tissue) & a & $\mathrm{cd}$ & $\mathrm{b}$ & e & $\mathrm{bc}$ & e & de \\
\hline & p-Coumaric acid & $50.38 \pm 1.380$ & $49.54 \pm 3.358$ & $43.34 \pm 5.464$ & $48.40 \pm 7.638$ & $6.98 \pm 1.116$ & $2.42 \pm 0.142$ & $53.76 \pm 5.542$ \\
\hline & ( $\mu \mathrm{g} / \mathrm{gr}$ fresh tissue) & a & a & a & a & $\mathrm{b}$ & b & a \\
\hline & m-Coumaric acid & $9.90 \pm 2.514$ & $13.02 \pm 1.034$ & $4.08 \pm 0.064$ & $1.80 \pm 0.118$ & $9.48 \pm 0.492$ & $1.92 \pm 0.266$ & $6.38 \pm 2.598$ \\
\hline & ( $\mu \mathrm{g} / \mathrm{gr}$ fresh tissue) & $\mathrm{ab}$ & a & $\mathrm{cd}$ & d & $\mathrm{ab}$ & $\mathrm{d}$ & $\mathrm{bc}$ \\
\hline & Ferulic acid ( $\mu \mathrm{g} / \mathrm{gr}$ & $15.00 \pm 3.272$ & $14.44 \pm 2.126$ & $10.40 \pm 2.640$ & $11.12 \pm 2.288$ & $12.22 \pm 0.032$ & $3.46 \pm 0.156$ & $13.00 \pm 2.532$ \\
\hline & fresh tissue) & a & a & a & a & a & b & a \\
\hline & Caftaric acid ( $\mu \mathrm{g} /$ & $56.58 \pm 10.320$ & $25.70 \pm 0.930$ & $16.90 \pm 0.140$ & $15.08 \pm 0.494$ & $52.74 \pm 4.092$ & $11.38 \pm 1.778$ & $13.14 \pm 2.066$ \\
\hline & gr fresh tissue) & a & $b$ & bc & bc & a & c & $\mathrm{bc}$ \\
\hline & Coutaric acid ( $\mu \mathrm{g} /$ & $1.92 \pm 0.992$ & $0.66 \pm 0.084$ & $0.82 \pm 0.202$ & $0.80 \pm 0.174$ & $3.48 \pm 1.076$ & $0.52 \pm 0.260$ & $2.50 \pm 0.856$ \\
\hline & gr fresh tissue) & $\mathrm{ab}$ & $\mathrm{b}$ & $\mathrm{b}$ & $\mathrm{b}$ & a & $\mathrm{b}$ & $\mathrm{ab}$ \\
\hline & Fertaric acid ( $\mu \mathrm{g} /$ & $14.9 \pm 2.242$ & $18.40 \pm 1.072$ & $18.40 \pm 0.692$ & $18.72 \pm 1.404$ & $33.90 \pm 0.558$ & $19.42 \pm 1.558$ & $41.32 \pm 3.720$ \\
\hline & gr fresh tissue) & c & c & c & c & $b$ & c & a \\
\hline \multirow{6}{*}{ Stilbenes } & trans-resveratrol & $187.82 \pm 22.318$ & $157.24 \pm 3.528$ & $138.52 \pm 1.678$ & $45.00 \pm 2.170$ & $107.92 \pm 3.168$ & $57.26 \pm 2.568$ & $67.14 \pm 14.350$ \\
\hline & ( $\mu \mathrm{g} / \mathrm{gr}$ fresh tissue) & a & $\mathrm{ab}$ & $\mathrm{bc}$ & $\mathrm{d}$ & c & d & $\mathrm{d}$ \\
\hline & $\varepsilon-V$ iniferin $(\mu \mathrm{g} / \mathrm{gr}$ & $142.48 \pm 26.680$ & $88.58 \pm 5.440$ & $56.68 \pm 1.064$ & $58.66 \pm 1.184$ & $107.28 \pm 2.824$ & $64.44 \pm 3.372$ & $58.52 \pm 11.460$ \\
\hline & fresh tissue) & $\mathrm{a}$ & bc & c & c & $b$ & c & c \\
\hline & Piceid ( $\mu \mathrm{g} / \mathrm{gr}$ fresh & $68.84 \pm 11.568$ & $86.14 \pm 8.638$ & $25.64 \pm 13.148$ & $47.40 \pm 0.346$ & $20.72 \pm 2.326$ & $3.70 \pm 1.496$ & $55.28 \pm 6.782$ \\
\hline & tissue) & $\mathrm{ab}$ & a & $\mathrm{cd}$ & bc & $\mathrm{d}$ & $\mathrm{d}$ & $\mathrm{b}$ \\
\hline \multirow{2}{*}{ Phenolic aldehyde } & Vanillin ( $\mu \mathrm{g} / \mathrm{gr}$ & $0.96 \pm 0.548$ & $0.96 \pm 0.400$ & $0.58 \pm 0.024$ & $0.38 \pm 0.180$ & $2.64 \pm 0.356$ & $0.34 \pm 0.052$ & $1.36 \pm 0.354$ \\
\hline & fresh tissue) & $\mathrm{bc}$ & $\mathrm{bc}$ & $\mathrm{bc}$ & bc & a & c & $\mathrm{b}$ \\
\hline
\end{tabular}


104

More specifically, the grapevine variety 'Kolliniatiko' showed the highest concentration of trans-resveratrol with no statistically significant difference compared to 'Bekari', as well as the highest concentration of $\varepsilon$-viniferin, but with statistically significant difference compared to the other studied varieties. The grapevine variety 'Bekari' presented the highest value of piceid, with no statistically significant difference compared to 'Kolliniatiko'. The concentration of the three stilbenes (trans-resveratrol, $\varepsilon$-viniferin, piceid) of the varieties of the current study proved to be higher in comparison with other varieties in a previous study (Anastasiadi et al., 2010).

The grapevine variety 'Doubrena mavri' recorded the highest concentration of vanillin, which is the only one of phenolic aldehydes that influences wine aroma (MorrenoArribas and Polo, 2009), with statistically significant difference compared to the other studied varieties.

It should be noted that the differentiations which were observed in the phenolic profile of the studied varieties, were also observed in the case of grapevine varieties 'Mavro Spetson', 'Kountoura mavri' and 'Doubrena mavri', which are all considered genetically related (Stavrakaki and Biniari, 2017). The results of the present study showed that 'Mavro Spetson' was characterized by higher concentrations of berry skin total phenols, total flavonoids, condensed tannins, total flavanols, catechin and epicatechin. On the other hand, 'Kountoura mavri' showed the highest concentrations of seed total phenolics, total flavonoids and condensed tannins, while 'Doubrena mavri' presented the highest concentrations of berry skin luteolin, gallic acid and vanillin.

\section{Conclusions}

In the present study, total and individual anthocyanin and phenolic content of seven indigenous cultivated varieties were evaluated for the first time in grapes. Up to five anthocyanidin-3-O- glucosides and twenty-three individual phenols were identified and quantified. From the studied varieties, the grapevine varieties 'Kountoura mavri' and 'Mavro Spetson' have the phenolic and anthocyanin potential that can produce high quality wines with ageing potential. The grapevine variety 'Doubrena mavri' has lower phenolic potential compared to the other varieties, while it shows the highest concentration of vanillin. The grapevine variety 'Mavro Spetson' exhibits (a) the highest concentration of quercetin and tannins, (b) the lowest concentration of gallic acid, attributes that makes it suitable to produce ageing wines. This is also very important for the exploitation of certain varieties for the production of different types of wines in combination with different terroirs. From all the studied varieties, the grapevine variety 'Kolliniatiko' is characterized by the highest anthocyanin potential, the highest sugar content and by an adequate total acidity, which requires further evaluation for its exploitation in the Greek vineyard. In all, the studied grapevine varieties recorded the highest concentration of skin and seed total phenolics and adequate anthocyanin content.

\section{Acknowledgements}

This research received no specific grant from any funding agency in the public, commercial, or not-for-profit sectors.

\section{References}

Anastasiadi M, Pratsinis H, Kletsas D, Skaltsounis AL, Haroutounian SA (2010). Bioactive non-coloured polyphenols content of grapes, wines and vinification by-products: evaluation of the antioxidant activities of their extracts. Food Research International 43:805-813.

Bonvehi JS, Coll FV, Jorda RE (1994). The composition, active components and bacteriostatic activity of propolis in dietetics. Journal of the American Oil Chemists' Society 71:529-532.

Boss PK, Davies C (2009). Molecular biology of anthocyanin accumulation in grape berries. Grapevine Molecular Physiology \& Biotechnology. Ed: Roubelakis-Angelakis KA pp 265-268.

Bourzeix M, Weyland D, Heredia N (1986). Etude des catechines et des procyanidols de la grappe de raisin, du vin et d'autres derives de la vigne. Bullettin del'OIV 59(669-670):1175-1254.

Castilla P, Echarri R, Dávalos A, Cerrato F, Ortega H, Teruel JL, ... Lasunción MA (2006). Concentrated red grape juice exerts antioxidant, hypolipidemic, and antiinflammatory effects in both hemodialysis patients and healthy subjects. American Journal of Clinical Nutrition 84:252-262.

Cheynier V, Rigaud J (1986). HPLC separation and characterization of flavonols in the skins of Vitis vinifera var. Cinsault. American Journal of Enology and Viticulture 37:248-252.

Chiou A, Panagopoulou EA, Gatzali F, De Marchi S, Karathanos VT (2014). Anthocyanins content and antioxidant capacity of Corinthian currants (Vitis vinifera L, var. Apyrena). Food Chemistry 146:157-165.

Coimbra SR, Lage SH, Brandizzi L, Yoshida V, da Luz PL (2005). The action of red wine and purple grape juice on vascular reactivity is independent of plasma lipids in hypercholesterolemic patients. Brazilian Journal of Medical and Biological Research 38:1339-1347.

Dewanto V, Wu X, Adom KK (2002). Thermal processing enhances the nutritional value of tomatoes by increasing total antioxidant activity.Journal of Agricultural and Food Chemistry 50:3010-3014.

Di Stefano R, Flamini R (2008). Hyphenated Techniques in Grape and Wine Chemistry. CRA, Viticulture Research Center, Conegliano Veneto, Italy.

Fernández de Simón B, Hernández T, Estrella I (1993). Phenolic composition of white grapes (Var Airen). Changes during ripening. Food Chemistry 47:47-52.

Folts JD (1998). Antithrombotic potential of grape juice and red wine for preventing heart attacks. Pharmaceutical Biology 36(5):21-27.

Freedman JE, Parker C $3^{\text {rd }}$, Li L, Perlman JA, Frei B, Ivanov V, ... Folts JD (2001). Select flavonoids and whole juice from purple grapes inhibit platelet function and enhance nitric oxide release. Circulation 103:2792-2798. 
Hansen AS, Marckmann P, Dragsted LO, Finne Nielsen IL, Nielsen, SE, Gronbaek M (2005). Effect of red wine and red grape extract on blood lipids, haemostatic factors, and other risk factors for cardiovascular disease. European Journal of Clinical Nutrition 59:449-455.

Hollecker L, Pinna M, Filippino G, Scrugli S, Pinna B, Argiolas F, Murru M (2009). Simultaneous determination of polyphenolic compounds in red and white grapes grown in Sardinia by high performance liquid chromatography-electron spray ionizationmass spectrometry. Journal of Chromatography A 1215:34023408.

Iacopini P, Baldi M, Storchi P, Sebastiani L (2008). Catechin, epicatechin, quercetin, rutin and resveratrol in red grape: Content, in vitro antioxidant activity and interactions. Journal of Food Composition and Analysis 21:589-598.

Kallitraka S, Tsoutsouras E, Tzourou E, Lanaridis P (2006). Principal phenolic compounds in Greek red wines. Food Chemistry 99(4):784-793.

Kammerer D, Claus A, Carle R, Schieber A (2004). Polyphenol screening of pomace from red and white grape varieties (Vitis vinifera L.) by HPLC-DAD-MS/MS. Journal of Agricultural and Food Chemistry 52:4360-4367.

Keevil JG, Osman HE, Reed JD, Folts JD (2000). Grape juice, but not orange juice or grapefruit juice, inhibits human platelet aggregation. Journal of Nutrition 130:53-56.

Lekakis J, Rallidis LS, Andreadou I, Vamvakou G, Kazantzoglou G, Magiatis P, ... Kremastinos DT (2005). Polyphenolic compounds from red grapes acutely improve endothelial function in patients with coronary heart disease. European Journal of Cardiovascular Prevention and Rehabilitation 12:596-600.

Li YG, Tanner G, Larkin P (1996). The DMACA-HCl protocol and the threshold proanthocyanidin content for bloat safety in forage legumes. Journal of the Science of Food and Agriculture 70:89-101.

Lorrain B, Chira K, Teissedre PL (2011). Phenolic composition of Merlot and Cabernet-Sauvignon grapes from Bordeaux vineyard for the 2009-vintage: Comparison to 2006, 2007 and 2008 vintages. Food Chemistry 126:1991-1999.

Makris DP, Kallithraka S, Kefalas P (2006). Flavonols in grapes, grape products and wines: burden, profile and influential parameters. Journal of Food Composition and Analysis 19(5):396-404.

McMorrough I, Madigan D, Smyth MR (1996). Semipreparative chromatographic procedure for the isolation of dimeric and trimeric proanthocyanidins from barley. Journal of Agricultural and Food Chemistry 44:1731-1735.

Moreno-Arribas MV, Polo C (2009). Wine Chemistry and Biochemistry. Springer Science+Business Media, LLC, 233 Spring Street, New York, NY 10013, USA.

Mozetič B, Tomažič I, Škvarč A, Trebše P (2006). Determination of polyphenol is in white grape berries cv. Rebula. Acta Chimica Slovenica 53:58-64.

Nicoletti I, Bello C, De Rossi A, Corradini D (2008). Identification and quantification of phenolic compounds in grapes by HPLC-PDAESI-MS on a semimicro separation scale. Journal of Agricultural and Food Chemistry 56:8801-8808.
Pace-Asciak CR, Rounova O, Hahn SE, Diamandis EP, Goldberg DM (1996). Wines and grape juices as modulators of platelet aggregation in healthy human subjects. Clinica Chimica Acta 246:163-182.

Park YK, Kim JS, Kang MH (2004). Concord grape juice supplementation reduces blood pressure in Korean hypertensive men: double-blind, placebo controlled intervention trial. Biofactors 22:145-147.

Pastrana-Bonilla E, Akoh CC, Sellappan S, Krewer G (2003). Phenolic content and antioxidant capacity of Muscadine grapes. Journal of Agricultural and Food Chemistry 51:5497-5503.

Petropoulos S, Kanellopoulou A, Paraskevopoulos I, Kotseridis G, Kallithraka S (2017). Characterization of grape and wine proanthocyanidins of Agiorgitiko (Vitis vinifera L. cv.) cultivar grown in different regions of Nemea. Journal of Food Composition and Analysis (in press).

Revilla E, Ryan JM (2000). Analysis of several phenolic compounds with potential antioxidant properties in grape extracts and wines by highperformance liquid chromatography-photodiode array detection without sample preparation. Journal of Chromatography A 881:169-461.

Ribereau-Gayon P, Dubourdieu D, Doneche B, Lonvaud A (2006). Handbook of Enology (vols. 1 and 2). The Microbiology of Wine and Vinification. John Wiley and Sons, Ltd, Chichester, UK

Sakkiadi AV, Georgiou CA, Haroutounian SA (2007). A standard addition method to assay the concentration of biologically interesting polyphenols in grape berries by reversed-phase HPLC. Molecules 12(9):2259-2269.

Sarneckis CJ, Dambergs RG, Jones P, Mercurio M, Herderich MJ, Smith PA (2006). Quantification of condensed tannins by precipitation with methyl cellulose: development and validation of an optimised tool for grape and wine analysis. Australian Journal of Grape and Wine Research 12:39-49.

Seddon TJ, Downey MO (2008). Comparison of analytical methods for the determination of condensed tannins in grape skins. Australian Journal of Grape and Wine Research 14:54-61.

Shirkande AJ (2000). Wine byproducts with health benefits. Food Research International 33:469-474.

Somers TC, Evans ME (1977). Spectral evaluation of young red wines: anthocyanin equilibria, total phenolic, free and molecular $\mathrm{SO}_{2}$, 'Chemical age'. Journal of the Science of Food and Agriculture 28:279-287.

Stavrakaki M, Biniari K (2017). Ampelographic and genetic characterization of grapevine varieties (Vitis vinifera L.) of the 'Mavroudia' group cultivated in Greece. Notulae Botanicae Horti Agrobotanici Cluj-Napoca 45(2):525-531.

Stavrakakis MN (2013). Viticulture. Tropi Publications, Athens.

Stein JH, Keevil JG, Wiebe DA, Aeschlimann S, Folts JD (1999). Purple grape juice improves endothelial function and reduces the susceptibility of LDL cholesterol to oxidation in patients with coronary artery disease. Circulation 100:1050-1055.

Tsaparas DI (2013). Study of the effect of potassium fertilization on the phenolic composition of Vitis vinifera var. 'Agiorgitiko' for the year 2010. MSc Dissertation, Agricultural University of Athens. 
106

Vivas N, Glories Y, Lagune L, Saucier C, Augustin M (1994). Estimation du degré de polymerisation des procyanidins du raisin et $\mathrm{du}$ vin par la méthode au p-dimethylaminocinnamaldehyde. Journal International des Sciences de la Vigne et du Vin 28(4):319336.

Vrhovšek U (1998). Extraction of hydroxycinnamoyltartaric acids from berries of different grape berries. Journal of Agricultural and Food Chemistry 46:4203-4208.
Waterhouse AL, Ignelzi E, Shirley JR (2000). A comparison of methods for quantifying oligomeric proanthocyanidins from grape seed extracts. American Journal of Enology and Viticulture 51:383-389.

Zern TL, Wood RJ, Greene C, West KL, Liu Y, Aggarwal D, ... Fernandez ML (2005). Grape polyphenols exert a cardioprotective effect in pre-and postmenopausal women by lowering plasma lipids and reducing oxidative stress. Journal of Nutrition 135:1911-1917. 